\title{
PENGARUH GAYA KEPEMIMPINAN, KEPUASAN KERJA DAN MOTIVASI TERHADAP KINERJA KARYAWAN TOP YUMMY DI JAKARTA
}

\author{
Rayen Eduard Wijaya \\ Program Studi Magister Manajemen Universitas Tarumanagara \\ rayeneduard@gmail.com
}

\begin{abstract}
The purpose of this study was to determine the effect of leadership, job satisfaction, motivation, on employee performance. The sample selection technique used in this study is a non-probabilty sampling method, namely purposive sampling. The population of this research is the Jakarta branch of Top Yummy employees. The research sample was taken from 100 respondents who had worked at least 6 months at the Top Yummy Jakarta branch. Data analysis using SmartPLS 3.0. Data collection is done by distributing questionnaires. The results are: (a) leadership has a positive and significant influence on employee performance in the Jakarta branch of Top Yummy, (b) job satisfaction has a positive and significant influence on the employee performance of the Jakarta branch of Top Yummy. (c) Motivation has a positive and significant influence on employee performance at the Jakarta branch of Top Yummy
\end{abstract}

Keywords : Leadership, Job Satisfaction, Motivation, Employee Performance.

Abstrak : Tujuan dari penelitian ini adalah untuk mengetahui pengaruh antara kepemimpinan, kepuasan kerja, motivasi, terhadap kinerja karyawan. Teknik pemilihan sampel yang digunakan dalam penelitian ini adalah metode non-probabilty sampling, yaitu purposive sampling. Populasi penelitian ini adalah karyawan Top Yummy cabang Jakarta. Sampel penelitian ini diambil dari 100 responden yang telah bekerja minimal 6 bulan di Top Yummy cabang Jakarta. Data analisis menggunakan SmartPLS 3.0. Pengumpulan data dilakukan dengan menyebarkan kuesioner. Hasilnya adalah: (a) kepemimpinan memiliki pengaruh positif dan signifikan terhadap kinerja karyawan di Top Yummy cabang Jakarta, (b) kepuasan kerja memiliki pengaruh positif dan signifikan terhadap kinerja karyawan Top Yummy cabang Jakarta. (c) Motivasi memiliki pengaruh positif dan signifikan terhadap kinerja karyawan di Top Yummy cabang Jakarta

Kata kunci : Kepemimpinan, Kepuasan Kerja, Motivasi, Kinerja Karyawan.

\section{Latar Belakang}

Selama beberapa waktu ini Industri Restoran merupakan salah satu usaha yang cukup berkembang dan di minati oleh masyarakat di negara Indonesia. Restoran merupakan salah satu tempat yang digunakan oleh masyarakat sebagai sarana hiburan sekaligus tempat untuk menikmati makanan. Seiring perkembangan jaman pola hidup masyarakat Indonesia semakin berkembang. Sehingga banyak masyarakat yang memilih untuk mengkonsumsi makanan diluar rumah. Hal tersebut disebabkan oleh banyak faktor, diantaranya adalah faktor waktu, suasana yang mendukung dan lingkungan. Menurut kompas.com di kota besar dalam setahun ke belakang ini pada kuartal 2 Tahun 2016 penjualan konsumsi di luar rumah berkontribusi besar pada kategori seperti kopi siap minum (50\%), camilan (49\%), minuman soda (45\%) dan berbagai kategori lainnya (Murhayati dalam Primus 2016). Karena pola hidup itu yang memicu indrustri makanan untuk semakin berkembang sehingga bisnis tersebut sampai saai ini masih diyakini sebagai salah satu bisnis yang memiliki prospek yang cukup bagus.

Seiring perkembangan jaman yang semakin pesat Indrustri restoran harus mampu bersaing bersama kepada para kompetitor. Untuk mempertahankan konsumen tentunya restoran pun harus berinovasi dengan menu variasi lainnya ditambah suasana yang mengikuti 
tren masa kini, dan harus nyaman untuk semua segmen dari yang muda sampai yang sudah berumur di mana strategi tersebut harus mampu diprediksikan oleh pihak restoran. Untuk menghadapi pesaing restoran Top Yammie perlu memiliki strategi agar selalu memberikan layanan yang terbaik kepada siapapun yang membeli makanan Top Yammie. Dengan begitu konsumen akan memberikan referensi kepada Konsumen dari keluarga, teman, maupun orang lain. Manajer dari restoran Top Yammie seharusnya mampu memimpin usahanya dan mengelola sumber daya yang dimiliki perusahaan dengan baik. Oleh karena itu diperlukan gaya kepemimpinan yang baik dari leader agar karyawan memiliki rasa loyalitas yang tinggi terhadap perusahaan.

\section{Kajian Teori}

Menurut Northouse (2013:5) kepemimpinan merupakan suatu proses dimana seorang individu mempengaruhi sekelompok individu untuk mencapai tujuan Bersama. Sementara itu kepemimpinan berkait erat dengan pola perilaku yang terlibat dalam Pemimpin ketika berhadapan dengan karyawan (Lippit dan White dalam Mohammed et al 2014).

Menurut Spector (dalam Javed et al 2014) Kepuasan kerja adalah berkaitan dengan seseorang bagaimana mempersepsikan, berpikir, dan merasa tentang pekerja dari mereka sendiri. Kepuasan kerja berkaitan bukan berarti seberapa keras atau seberapa baik seseorang dalam bekerja, melainkan seberapa jauh seseorang menyukai pekerjaan tertentu (Hughes et al 2012:312). Kemudian berdasarkan pendapat Sutrisno (2015:74).

Menurut Robbin dan Coulter (dalam Winardi 2011:2) motivasi adalah kesediaan dalam melaksanakan upaya untuk pencapaian tujuan organisasi yang dikondisikan melalui upaya untuk memenuhi kebutuhan individu. Motivasi merupakan kekuatan yang mendorong dalam menciptakan kegairahan bekerja seseorang yang bertujuan untuk mencapai tujuan organisasi (Eskanyua \& Mukuru 2013).

Kinerja karyawan adalah hasil kerja secara kualitas dan kuantitas yang dicapai oleh seorang karyawan dalam melaksanakan tugasnya sesuai dengan tanggung jawab yang diberikan kepadanya (Mangkunegara 2014;9).

Penelitian yang dilakukan oleh Setyowati dan Haryani (2016) ingin melihat sejumlah pengaruh Gaya Kepemimpinan, Motivasi dan Kompetensi terhadap kinerja karyawan pada restoran Taman Pringsewu yang berada di Yogyakarta. Populasi dalam penelitian tersebut sebanyak 32 orang. Dalam melakukan pengumpulan data penelitian tersebut menggunakan Teknik analisis regresi berganda dan teknik kuisioner dimana teknik pengumpulan data yang dilakukan dengan cara member seperangkat pernyataan secara tertulis yang ditunjukkan kepada responden. Dari hasil penelitian tersebut menyenangkan bahwa Gaya Kepemimpinan, Motivasi dan kompensasi secara simultan berpengaruh positif terhadap kinerja karyawan.

Penelitian yang dilakukan oleh Sari (2012), Fokusnya penelitian ini dilakukan pada restoran ikan bakar yang berada di Malang ingin melihat faktor-faktor apa saja yang mempengaruhi kinerja karyawan. Jumlah sampel yang dilakukan pada penelitian tersebut sebanyak 53 sampel yang dijadikan sebagai responden dengan menggunakan Teknik analisis regresi linear berganda. Dalam melakukan pengumpulan data penelitian tersebut menggunakan cara menyebarkan kuisioner dimana dengan memberi seperangkat pertanyaan secara tertulis dan ditunjukkan kepada responden dari hasil tersebut mengatakan bahwa ada faktor kepuasan kerja yang berpengaruh untuk bisa meningkatkan kinerja karyawan yang meliputi kondisi lingkungan, kondisi kerja, waktu istirahat, Maupun komunikasi antar karyawan.

Penelitian yang dilakukan oleh Kasenda (2013) ingin melihat sejauh mana pengaruh kompensasi dan motivasi terhadap kinerja karyawan pada PT. Bangun wenang Beverages Company yang berada di Manado. Populasi dalam penelitian tersebut sebanyak 147 orang dengan sampel yang digunakan untuk dijadikan responden sebanyak 60 orang. Dalam melakukan pengumpulan data penelitian tersebut menggunakan Teknik Kuisioner, dan penelitian kepustakaan dengan menggunakan teknis analisi regresi berganda. Dari hasil 
penelitian tersebut menyatakan bahwa kompensasi dan motivasi secara simulyan berpengaruh positif terhadap kinerja karyawan.

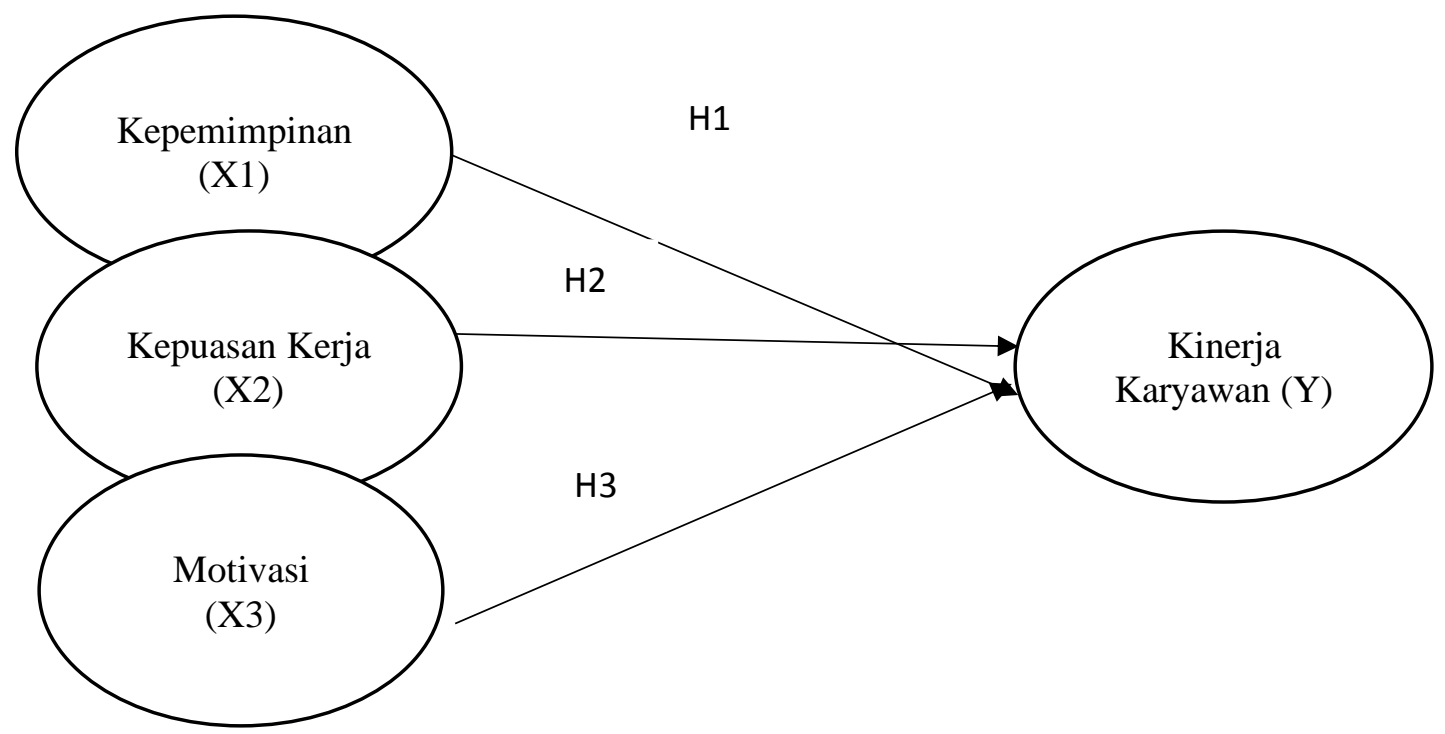

Gambar 1. Kerangka Pemikiran

Hipotesis tentang pengaruh antara pelatihan dan motivasi dengan kerja karyawan pada Top Yammie adalah sebagai berikut :

H1. Terdapat pengaruh yang signifikan dari gaya kepemimpinan terhadap kinerja karyawan pada Restoran Top Yammie

$\mathrm{H} 2$. Terdapat pengaruh yang signifikan dari kepuasan kerja terhadap kinerja karyawan pada Restoran Top Yammie

H3. Terdapat pengaruh yang signifikan dari motviasi terhadap kinerja karyawan pada restoran Top Yammie

\section{Metodologi}

Subjek penelitian. Penelitian ini akan diuraikan sebanyak 100 responden yang ditinjau dari jenis kelamin, usia, pendidikan terakhir, dan lama bekerja. Objek Penelitian. Penelitian ini difokuskan pada karyawan Yop Yummy cabang Jakarta. Dimana sampel responden yang didapat berjumlah 100 orang dengan kriteria yang telah bekerja selama 3 bulan. Pemilihan sampel dilakukan dengan purposive sampling yang disebar menggunakan kuesioner. Variabel operasional dalam penelitian ini terdiri dari kepemimpinan, kepuasan kerja, dan motivasi sebagai variabel independen dan kinerja karyawan sebagai variabel dependen. Pengukuran menggunakan skala likert 5 poin

Dalam penelitian ini menggunakan Uji Validitas Konvergen dan Uji Validitas Diskriminan. dan Uji Reliabilitas Cronbach's Alpha dan Uji Reliabilitas Composite Reliability. Sedangkan Uji Hipotesis menggunakan Uji t-statistik.

\section{Hasil Uji Statistik}

Tabel 1 Hasil pengujian outer model

\begin{tabular}{|c|c|c|}
\hline \multicolumn{1}{|c|}{ Konstruk } & Loadings \\
\hline Kepemimpinan: AVE $=0.553, \mathrm{CR}=0.910$ & 0.806 \\
\hline K1 & $\begin{array}{l}\text { Dalam menjalankan pekerjaan , atasan saya tidak } \\
\text { menimbulkan rasa takut dan memberikan ancaman bagi } \\
\text { bawahannya. }\end{array}$ & $\begin{array}{l}\text { Semua jenis kewenangan dan keputusan dalam pekerjaan } \\
\text { hanya berpusat pada atasan }\end{array}$ \\
\hline K2 & 0.769 \\
\hline
\end{tabular}




\begin{tabular}{|c|c|c|}
\hline K3 & $\begin{array}{l}\text { Dalam menjalankan pekerjaan atasan saya selalu menuntut } \\
\text { hasil yang sempurna }\end{array}$ & 0.731 \\
\hline K4 & $\begin{array}{l}\text { Dalam menjalankan tugas atasan juga ikut berpartisipasi } \\
\text { membantu karyawan }\end{array}$ & 0.722 \\
\hline K5 & Dalam menjalankan tugas atasan saya bersikap sangat Persuasi & 0.732 \\
\hline K6 & Atasan saya sangat memperhatikan perasaan bawahannya & 0.715 \\
\hline K7 & Atasan saya tidak sibuk dengan urusan administratif & 0.715 \\
\hline K8 & Atasan saya tidak menjaga jarak dengan bawahannya & 0.778 \\
\hline K9 & $\begin{array}{l}\text { Atasan saya ikut berpartisipasi dalam mengambil keputusan } \\
\text { bagi bawahannya }\end{array}$ & 0.723 \\
\hline \multirow[t]{2}{*}{ K10 } & Atasan saya selalu percaya terhadap hasil kerja bawahannya & 0.739 \\
\hline & Kepuasan Kerja $: \mathrm{AVE}=0.616, \mathrm{CR}=0.792$ & \\
\hline KK1 & $\begin{array}{l}\text { Perusahaan memberikan pekerjaan yang diberikan sesuai minat } \\
\text { dan kemampuan }\end{array}$ & 0.809 \\
\hline KK2 & $\begin{array}{l}\text { Setiap pekerjaan dapat saya selesaikan dengan baik bila adanya } \\
\text { dukungan antar rekan kerja }\end{array}$ & 0.724 \\
\hline KK3 & $\begin{array}{l}\text { Perusahaan memeberikan gaji yang sesuai dengan tugas yang } \\
\text { saya lakukan }\end{array}$ & 0.778 \\
\hline \multirow[t]{2}{*}{ KK4 } & $\begin{array}{l}\text { Perusahaan membuat kondisi tempat kerja yang nyaman serta } \\
\text { menyediakan sarana yang dibutuhkan }\end{array}$ & 0.823 \\
\hline & Motivasi : $\mathrm{AVE}=0.588, \mathrm{CR}=0.842$ & \\
\hline KN1 & $\begin{array}{l}\text { Karyawan mampu mencapai kuantitas pekerjaan sesuai atau } \\
\text { yang ditetapkan }\end{array}$ & 0.768 \\
\hline KN2 & $\begin{array}{l}\text { Karyawan dapat memenuhi standar kualitas yang telah } \\
\text { ditetapkan perusahaan }\end{array}$ & 0.722 \\
\hline KN3 & Karyawan memiliki proses kerja yang baik & 0.766 \\
\hline KN4 & Karyawan dapat menyelesaikan tugas secara tepat waktu & 0.748 \\
\hline \multirow[t]{2}{*}{ KN5 } & $\begin{array}{l}\text { Karyawan hadir secara tepat waktu dan memperhatikan jumlah } \\
\text { ketidak hadiran mereka }\end{array}$ & 0.826 \\
\hline & Kinerja Kerja $: \mathrm{AVE}=0.612, \mathrm{CR}=0.824$ & \\
\hline M1 & $\begin{array}{l}\text { Saya memperoleh penghasilan yang dapat digunakan dalam } \\
\text { memenuhi kebutuhan fisik }\end{array}$ & 0.783 \\
\hline M2 & $\begin{array}{l}\text { Saya mendapatkan keselamatan dan perlindungan terhadap } \\
\text { fisik dan emosional }\end{array}$ & 0.747 \\
\hline M3 & $\begin{array}{l}\text { Saya memiliki rasa kasih sayang dan persahabatan di } \\
\text { lingkungan pekerjaan }\end{array}$ & 0.773 \\
\hline M4 & Saya mendapatkan penghargaan atas faktor penghormatan diri & 0.830 \\
\hline
\end{tabular}




\begin{tabular}{|l|l|c|}
\hline \hline M5 & $\begin{array}{l}\text { Saya mendapatkan dorongan untuk menjadi seseorang yang } \\
\text { dapat memenuhi potensi dan kebutuhan diri }\end{array}$ & 0.777 \\
\hline
\end{tabular}

Keterangan : AVE = Average Variance Extracted, $\mathrm{CR}=$ Composite Reliability

Berdasarkan hasil uji outer model dapat dilihat bahwa seluruh indikator dari setiap variabel memenuhi syarat yang telah ditentukan yaitu nilai AVE lebih besar dari 0,5, loading factor lebih besar dari 0,5 dan CR lebih besar dari 0,7 sehingga dapat disimpulkan bahwa setiap indikator dan variabel yang digunakan dalam penelitian ini adalah valid dan reliabel.

Uji inner model yang dilakukan pada penelitian ini adalah uji koefisien determinasi $\left(\mathrm{R}^{2}\right)$ dan hasil yang di dapatkan adalah sebesar 0,838 yang berarti bahwa $83.8 \%$ dari variabel dependen yaitu minat pembelian dapat dijelaskan oleh variabel-variabel yang terdapat dalam penelitian ini dan sisanya yaitu $16.2 \%$ dijelaskan oleh variabel-variabel di luar penelitian ini. Uji selanjutnya adalah goodness of fit dan hasil yang didapatkan adalah 0,701 hal ini menunjukkan bahwa nilai atau tingkat kelayakan model penelitian ini dapat dinyatakan sedang. Berdasarkan teori uji nilai GoF yang dikembangkan oleh Tenenhaus (2005) nilai GoF terbagi menjadi 3 kategori yaitu kecil $=0,1$, sedang $=0,25$ dan besar $=0,38$.

Uji hipotesis dapat dilihat melalui $\mathrm{T}$ statistic atau $\mathrm{P}$ values di setiap variabel yang terdapat pada tabel path coefficients yang merupakan hasil kalkulasi pada bootstrapping. Kedua indikator ini dianalisis untuk melihat pengaruh serta signifikansinya.

Tabel 2 Hasil Bootstrapping

\begin{tabular}{|c|c|c|c|c|}
\hline Variables & $\begin{array}{c}\text { Original } \\
\text { Sample }\end{array}$ & $\begin{array}{c}\text { Standard } \\
\text { Deviations }\end{array}$ & T-statistics & P Values \\
\hline $\begin{array}{c}\text { Kepemimpinan } \rightarrow \text { Kinerja } \\
\text { Karyawan }\end{array}$ & 0.384 & 0.098 & 3.915 & 0.000 \\
\hline $\begin{array}{c}\text { Kepuasan Kerja } \rightarrow \text { Kinerja } \\
\text { Karyawan }\end{array}$ & 0.297 & 0.104 & 2.846 & 0.005 \\
\hline Motivasi Kerja $\rightarrow$ Kinerja Karyawan & 0.322 & 0.067 & 4.831 & 0.000 \\
\hline
\end{tabular}

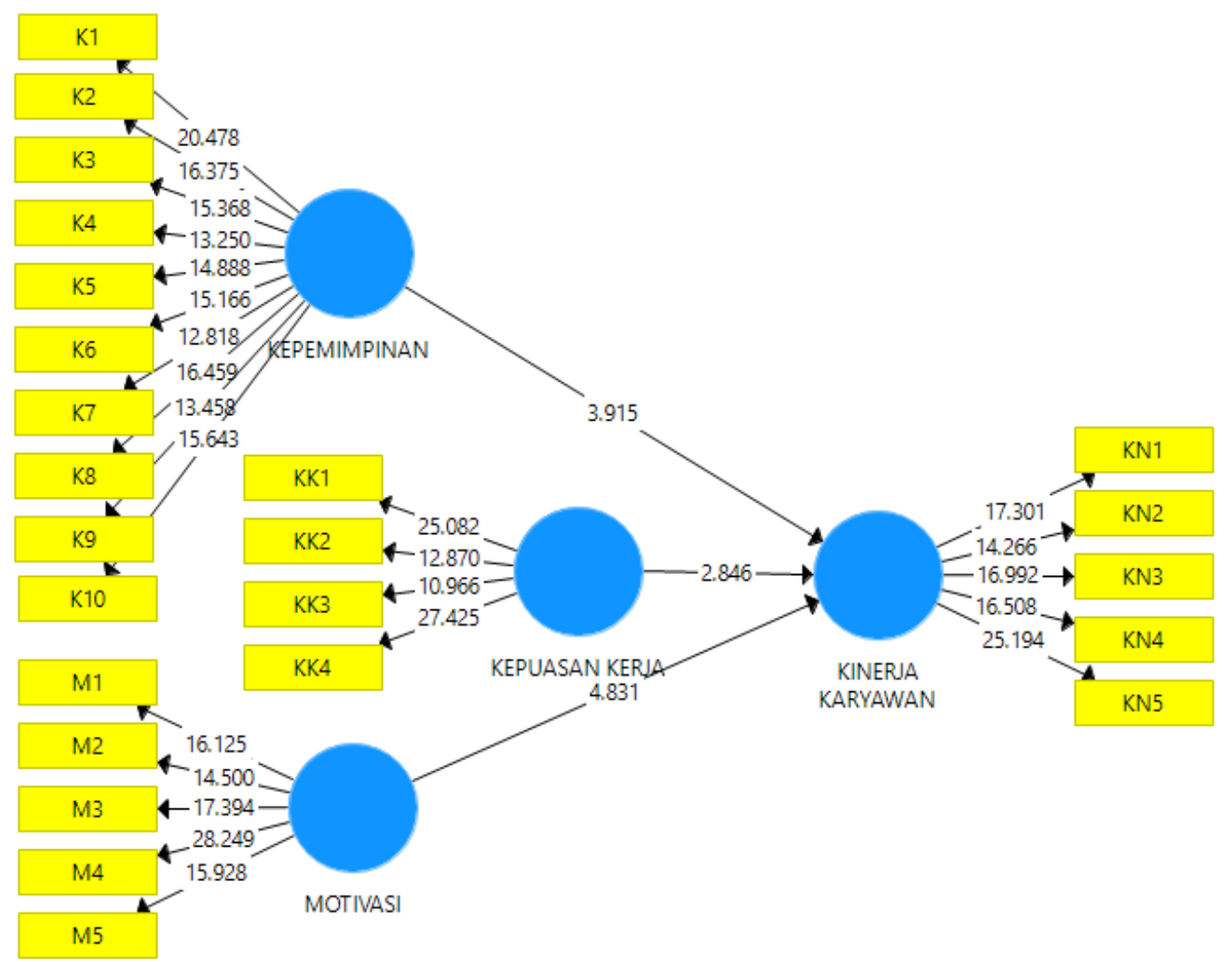

Gambar 2 Diagram Hasil Uji Bootstrapping 


\section{Pembahasan}

Berdasarkan hasil hipotesis 1, dapat dilihat bahwa terdapat pengaruh positif dan signifikan antara gaya kepemimpinan terhadap kinerja karyawan. Hasil penelitian ini juga sesuai dengan penelitian terdahulu yaitu penelitian yang dilakukan oleh Susilo Toto Raharjo, Durrotun Nafisah dengan judul Analisis pengaruh gaya kepemimpinan terhadap kepuasan kerja, komitmen organisasi dan kinerja karyawan (Studi empiris pada departemen agama kabupaten kendal dan departemen agama kotasemarang).

Berdasarkan hasil hipotesis 2, dapat dilihat bahwa terdapat pengaruh positif dan signifikan antara kepuasan kerja terhadap kinerja karyawan. Hasil penelitian ini juga sesuai dengan penelitian terdahulu yaitu penelitian yang dilakukan oleh Riski Damayanti, Agustina Hanafi, \& Afriyadi Cahyadi dengan judul Pengaruh kepuasan kerja terhadap kinerja karyawan (Studi kasus karyawan non medis RS Islam siti Khadijah Palembang).

Berdasarkan hasil hipotesis 3, dapat dilihat bahwa terdapat pengaruh positif dan signifikan antara motivasi terhadap kinerja karyawan. Hasil penelitianini juga sesuai dengan penelitian terdahulu yaitu penelitian yang dilakukan oleh Kiki Cahaya Setiawan dengan judul Pengaruh Motivasi kerja terhadap kinerja karyawan level pelaksana di divisi operasi PT. PUSRI Palembang.

\section{Penutup}

Berdasarkan hasil penelitian dan pembahasan yang dilakukan atas pengaruh kepemimpinan, kepuasan kerja dan motivasi terhadap kinerja karyawan pada Restoran Top Yummy cabang Jakarta, maka dapat diambil kesimpulan sebagai berikut: Kepemimpinan memiliki pegaruh positif yang signifikan terhadap kinerja karyawan. terdapat hasil uji t statistik yang menunjukkan bahwa hubungan antara Kepemimpinan dengan Kinerja Karyawan adalah signifikan dengan uji t statistik sebesar 3,915 (>1,96). Nilai original sample menunjukkan hasil sebesar 0.384 , artinya arah hubungan terdapat pengaruh signifikan dan positif anatra motivasi terhadap kinerja karyawan.

Terdapat pengaruh kepuasan kerja secara positif terhadap kinerja karyawan memiliki nilai yang signifikan. hasil uji t statistik yang menunjukkan bahwa hubungan antara Kepuasan Kerja dengan Kinerja Karyawan adalah tidak signifikan dengan uji t statistik sebesar 2,846 $(>1,96)$. Nilai original sample menunjukkan hasil sebesar 0.297, artinya arah hubungan antara kepuasan kerja dengan karyawan kinerja adalah positif. Hasil ini menunjukkan bahwa terdapat pengaruh yang signifikan dan positif antara kepuasan kerja terhadap kinerja karyawan.

Motivasi memiliki pegaruh positif yang signifikan terhadap kinerja karyawan. terdapat hasil uji t statistik yang menunjukkan bahwa hubungan antara Motivasi dengan Kinerja Karyawan adalah signifikan dengan uji t statistik sebesar $4.831(>1,96)$. Nilai original sample menunjukkan hasil sebesar 0.322 , artinya arah hubungan terdapat pengaruh signifikan dan positif anatra motivasi terhadap kinerja karyawan.

Di dalam melakukan penelitian ini, peneliti akan memberikan beberapa saran, sebagai berikut: Bagi Perusahaan Restoran Top Yummy selaku perusahaan jasacleaning servicelebih meningkatkan pelatihan yang lebih seperti minimum setahun 2 kali untuk karyawan yang memberi kontribusi besar terhadap perusahaan sehingga kinerja karyawan akan semakin meningkat. Restoran Top Yummy juga dapat meningkatkan indikator kepuasan kerja mengenai atasan bersikap adil dalam memperlakukan seluruh karyawan yang memiliki nilai bootstrapping terendah yaitu $(13,791)$ pada variabel kepuasan kerja. 


\section{Daftar Pustaka}

Arikunto, S., (2010). Prosedur Penelitian: Suatu Pendekatan Praktek. Edisi Keempat Jakarta: Rineka Cipta.

Bryman, A. (1992). Charisma and Leadership in Organization. London: Sage Publications.

Chaudhry, A. Q.,Javed, H \& Sabir, M. (2012). The Impact of Transformational and Transactional Leadership Style on The Motivation of Employee Pakistan. Pakistan Economic and social Review, 5(2), 223-231.

Eskanyua, K., \& Mukuru, E. (2013). Effect of Motivation on Employee Performance In Public Middle Level Technical Training Institutions In Kenya. International Journal of Advances in Management and Economics. 2(4) 73- 82.

French, R., Rayner, C., Rees, G .,\& Rumbles, S.( 2015).Organizational behavior. $3^{\text {rd }}$ Edition. John Wiley \& Sons, Inc. New York.

Ghiselli, E. E., \& Brown, C. W. (1950). Personnel and Industrial Psychology. Mc New York: Graw-hill.

Gray, J.L.,\& Starke, F. A. (1984). Organizational Behaviour, Concept, and Applications. Charles E., Merrill Publ. Company, Columbus.

Hackman, J \& Oldham, R. (1975). Development of the Job Diagnostic Survey. Journal of Applied Psychology, 60(2), 159-170.

Hughes, R. L., Ginnet, R. C., \& Curphy, G. C. (2012). Leadership: Memperkaya Pelajaran dari Pengalaman,Edisi 7. Jakarta: Salemba Humanika.

Javed, M., Balouch, R \& Hassan, F. (2014). Determinants of Job Satisfaction and its Impact on Employee Performance and Turnover Intentions. International Journal Of Learning and Development, 4(2). doi: 10.5296/ ijld.v4i2.6094.

Kasenda, R (2013). Kompensasi dan Motivasi Terhadap Kinerja Karyawan pada PT. Bangun Wenang Beverages Company Manado. Jurnal Emba Vol 1 No.3

Lippit, L \& White, R. (1939). Patterns of Aggressive Behavior in Artificially Created Social Change. Journal of Social Psychology, 10, 271-299.

Locke, E. (1976). The nature and causes of job satisfaction. In M.D. Dunnette (ed.), Handbook of industrial and organizational psychology, Rand Mcnally, Chicago, IL, pp.1297-349.

Mangkunegara, A. P. (2000). Manajemen Sumber Daya Manusia Perusahaan. Bandung: Remaja Rosdakarya

Mangkunegara, A. P . (2014). Evaluasi Kinerja SDM. Bandung: PT.Refika Aditama.

Mathis, R. L \& Jackson, J. H. (2008). Human Resource management (12th ed). South-Western: Thomson

McClelland, D. (1961). The Achieving Society. New Jersey: Van Nonstrand Company, Inc.

Mohammed, U. D., Yusuf, M. O., Sanni, I. M., Ifeyinwa, T. N.,Bature, N. U., \& Kazeem, A. O. (2014).The Relationship between Leadership Styles and Employees' Performance in Organizations (A Study of Selected Business Organizations in Federeal Capital Territory, Abuja Nigeria). European Journal of Business and Management, 6(22).

Northouse, P. G. (2013). Kepemimpinan Teori dan Praktek. Edisi Keenam. Jakarta Indeks.

Pangarso., A \& Ramadhyanti., V. (2015). Pengaruh Lingkungan Kerja Non Fisik Terhadap Kepuasan Kerja Dosen Tetap Studi Pada Fakultas Komunikasi Dan Bisnis Universitas Telkom Bandung. Jurnal Kinerja Vol 19, No.1, 172-19.

Primus, J. (2016, Oktober 18). Masyarakat Perkotaan Pilih Makan dan Minum Di Luar Rumah. Retrieved From http ://bisnis keuangan. kompas.com/read/2016/10/18/181037526/ masyarakat. perkotaan. pilih. makan. dan. minum. di.luar. rumah.

Riduwan \& Kuncoro, E. A. (2013). Cara Menggunakan dan Memakai Path Analysis (Analisis Jalur). Bandung, Alfabeta.

Robbin, S., \& Coulter, M. (1999). Management. Prentice Hall Inc., New Jersey. Roscahyo, A. (2013). Pengaruh Gaya Kepemimpinan Terhadap Kinerja Karyawan Pada Rumah Sakit 
Siti Khodijah Sidoarjo. Jurnal Ilmu \& Riset Manajemen. Vol 2 No.13

Sari, W. P. (2012). Faktor-faktor yang berpengaruh kinerja karyawan Restoran Ikan Bakar 52 Malang. Jurnal Administrasi Bisnis. Vol 2 No.12

Sarjono, H \& Julianita, W (2011) SPSS VS LISREL: Sebuah Pengantar, Aplikasi untuk Riset. Jakarta, Salemba Empat.

Satriowati, E., Paramita, P. D., \& Hasiholan, L. P. (2016). Pengaruh Gaya Kepemimpinan Transformasional, Kompensasi dan Komunikasi terhadap Kinerja Karyawan dengan Kepuasan Kerja sebagai Variabel Mediasi pada Laundry Elephant King. Journal Of Management Vol. 2. No.2

Sekaran, U \& Bougie, R. (2013). Research Methods For Business. United Kingdom: Jhon Wiley \& Sons Ltd.

Setyowati, I \& Haryani S (2016). Pengaruh Gaya Kepemimpinan, Motivasi dan Kompensasi Terhadap Kinerja Karyawan pada Restoran Taman Pringsewu Yogyakarta. Jurnal Ilmiah Manajemen Bisnis Dan Terapan Tahun XIII Vol2. No.2

Siagian, S. (2008). Manajemen Sumber Daya Manusia. Jakarta: Bumi Aksara Subakti A. (2013). Pengaruh Motivasi, Kepuasan, dan Sikap Kerja Terhadap Kinerja Karyawan di Café X Bogor. Binus Business Review Vol. 4 No.2

Sugiyono. (2006). Metode Penelitian Bisnis. Bandung, Alfabeta. Sutrisno, E. (2015). Manajemen Sumber Daya Manusia. Jakarta: Kencana

Soekarso., Sosro, A., Hidayat, C \& Putong, I. (2010). Teori Kepemimpinan. Jakarta, Mitra Wacana Media.

Spector, P. (1997) Satisfaction: Application, Assessment, Causes and Consequences. Sage, London.Timple, D (1992) Kinerja. Jakarta : PT Gramedia

Ukandu, N \& Ukpere, W. (2014). Factors Impacting Job Satisfaction of Employees in the Fast Food Industry in Cape Town. Mediterranean Journal of Social Sciences, 5 (3).

Uju, M. (2013). The Influence of Motivation on Employees' Performance: A Study of Some Selected Firms in Anambra State. Afrrev Ijah: An International Journal of Arts and Humanities, 2(3) 134-151.

Wijaya, T. (2009). Analisis Data Penelitian Menggunakan SPSS. Yogyakarta: Graha Ilmu.

Winardi. (2011). Motivasi dan Pemotivasian Dalam Manajemen. Jakarta: PT Raj Grafindo Persada.

Zameer, H., Ali, S., Nizar, W \& Amir, M. (2014). The Impact of the Motivation on the Employee's Performance in Beverage Industry of Pakistan. International Journal of Academic Research in Accounting, Finance and Management Sciences, 4(1), 293-298. doi: 10.6007/ijarafms/v4-i1/630. 